\title{
Investigating the Effect of Service Quality on Bank Customers' Satisfaction in Bangladesh
}

\author{
Md. Atikur RAHAMAN ${ }^{1}$, Md. Julfikar ALI², Zhang KEJING ${ }^{3}$, Rupali Dilip TARU ${ }^{4}$, Zahidur Rahman MAMOON
}

Received: August 01, 2020 Revised: September 06, 2020 Accepted: September 12, 2020

\begin{abstract}
In this competitive era, it has become a prerequisite for the financial firms providing banking services to understand and meet the customers' needs and demands to remain competitive in today's market environment. Without satisfying the customers, banking business cannot stand alone. To satisfy customers, it is often recommended to provide better quality banking services to the bank customers. Providing quality banking services has become a prime strategic tool for the banking sector nowadays. Therefore, the study investigates the effect of various dimensions of service quality of banking service on customer satisfaction in a developing country, Bangladesh. A total of 212 walking Bangladeshi banking customers participated in this research. A structured questionnaire was developed based on past research. SPSS is utilized for analysis and Likert scale was used in this study. Internal consistency of all items was found correct and a total of seven hypotheses were proposed. For testing, a 5\% significance level is considered for acceptance of hypothesis. The findings show that, except employee competency, all other variables such as reliability, assurance, tangibles, responsiveness, empathy, and access to service have positive influence on customer satisfaction. The study provides policy implications for the management boards of the banking sectors.
\end{abstract}

Keywords: Service Quality, Customer Satisfaction, Responsiveness, Reliability, Tangibles

JEL Classification Code: M10, M15, G20

\section{Introduction}

Customers are the key factor from an organizational point of view. Service quality is a continuous process to meet the customer needs in the best way and it is a key for success in competition. Research has shown that the degree of service

${ }^{1}$ First Author and Corresponding Author. Associate Professor, School of Economics \& Management, Jiujiang University, Jiangxi, China [Postal Address: 551 Qianjin Donglu, Jiujiang City, Jiangxi Province, 332000, P.R. China] E-mail: atik@jju.edu.cn

${ }^{2}$ Associate Professor, Department of Business Administration, The International University of Scholars (IUS), Bangladesh.

E-mail: jalidhaka2020@gmail.com

${ }^{3}$ Associate Professor, School of Economics \& Management, Jiujiang University, Jiangxi, China. E-mail: kejingzhang139@126.com

${ }^{4}$ Assistant Professor, Department of Commerce \& Management, Shri J.J.T. University-Rajasthan, India. E-mail: rtaru@live.com

${ }^{5}$ Senior Lecturer, Department of Business Administration, Eminence

College Uttara, Dhaka, Bangladesh. E-mail: zrm347@gmail.com

(C) Copyright: The Author(s)

This is an Open Access article distributed under the terms of the Creative Commons Attribution Non-Commercial License (https://creativecommons.org/licenses/by-nc/4.0/) which permits unrestricted non-commercial use, distribution, and reproduction in any medium, provided the original work is properly cited. quality might trigger business performance by retaining and acquiring customer base (Tran, 2020). Simultaneously, the banking sector has increasingly paid attention to quality of service as well as strived to reach high level of service to satisfy the clients (Titko et al., 2013). Currently, Bangladesh is known to be an emerging developing country (Hossain \& Asheq, 2020). The country has been achieving increasing economic growth (Hossain et al., 2019). Simultaneously, Bangladeshi banks have been swiftly progressing day-byday and the banking sector is facing huge competition.

In terms of service quality, scale of development, capital resources, distribution network, and technology, the Bangladeshi banking sector is competing in terms on all these factors that ensure customer satisfaction. The banking sector in Bangladesh is focusing on the role of service quality on customer satisfaction. Indeed, several Bangladeshi banks are not much interested in investing in research to understand and satisfy bank customer needs. But previous marketing studies indicate that providing excellent customer service is the key factor for competitiveness in relation of satisfying bank clients. Previous research findings are treated as a good reference for marketers in the banking sector in the context of customer satisfaction. 
Moreover, each bank needs to rely on research to effectively understand service quality and develop servicerelated effective marketing strategies, as banking is perceived service-based industry. Since, service quality is a crucial variable in affecting customer's behaviors (Le et al., 2019) and providing quality service is essential for maintaining customer satisfaction (Tabash et al., 2019), thus the goal of this study is to identify service quality dimensions that could be used to quantify customer satisfaction and to assess the effect of service quality dimensions (tangibles, responsiveness, empathy, assurance, reliability, access, financial aspect, and employee competence) on customer satisfaction in the Bangladeshi bank sector. This study endeavors to address this gap in the literature by examining customer satisfaction with service quality in Bangladeshi banks, a developing country context.

\section{Literature Review}

\subsection{Customer Satisfaction}

The concept of customer satisfaction has been one of the oldest and widely used terms in marketing literature. Customer satisfaction refers to the customer's general intention and perception based on their consumption or usage experience of a product or service (Boonlertvanich, 2019). It measures the customer's acumen and expectation regarding the consumed product or service's performance and evaluates whether the product or service performance has been able to satisfy customer's expectation (Sultana $\&$ Das, 2016). If the product or service fails to fulfil the customer's needs or wants, then the customer will remain dissatisfied, and if the service performance is consistent with customer's expectation, then the customer will be delighted and satisfied (Nguyen et al., 2020).

\subsection{Service Quality}

Based on a user-based approach, quality relates to satisfaction. The highest quality underlies the greatest satisfaction of consumers' likings (Yarimoglu, 2014). Service quality as well as customer satisfaction are critical determining factors for organizations in order to gain competitiveness, business development, and growth in the turbulent marketplace (Angelova \& Zekiri, 2011). Different explanations of service quality have been advanced by researchers. According to Rauch et al. (2015), to determine an inclusive evaluation of an organization, the management has to associate its performance with its customers' expectations and evaluate its own performance compared to rival organizations in an identical industry. Researchers decide on the definition of service quality, underling that service delivery can harmonize with, match, or dominate the requirements of shoppers. Service quality recovers customer satisfaction and cost management upsurges profit (Yarimoglu, 2014).

Parasuraman et al. (1991) suggested SERVQUAL is a service quality prototypical to measure the scale of modification between what consumers presume and their perceptions. Parasuraman et al. (1991) suggested ten dimensions of service quality: tangibles, reliability, responsiveness, competence, courtesy, credibility, security, access, communication, and understanding the customer. There has been recently an upsurge in the number of studies observing service quality as an indispensable instrument for banks. Most researchers have reprocessed the aspects of SERVQUAL prototypical so as to capture and recognize the interaction between service quality and customer satisfaction in banks. Service quality in the SERVQUAL prototypical tool comprises five dimensions: reliability, responsiveness, assurance, empathy, and tangibles. These dimensions are reintegrated in service quality aspects, which indicates that there is a inter connection co-existing between the expectations of customers and perception of services (Parasuraman et al., 1991). Yarimoglu (2014) put forth seven dimensions of service quality (i.e., tangibles, responsiveness, empathy, assurance, reliability, access, and employee competence) that might have a controlling impact on customer satisfaction. Therefore, in order to identify each factor's probable influence on the Bangladeshi bank customer's delight and satisfaction, the study adopted five dimensions of the SERVQUAL measurement and two other variables to examine the overall effect of service quality on customer satisfaction.

\subsection{Reliability}

Parasuraman et al. (1985), Parasuraman et al. (1988) and Parasuraman et al. (1994) established that reliability underlies companies' performance of a service appropriately for the first time. Furthermore, they demonstrate that companies struggle to accomplish promises and pay thoughtfulness to the results. Reliability has been classified as the leading dimension of the SERVQUAL service quality measurement. Study by Lam (2002) measured reliability as a major factor in the dimensions of the service quality prototypical. Baumann et al. (2017) stated that reliability measures the range to which customers may depend on the service assured by the providing business firm. We propose the following hypothesis:

H1: Reliability affects customer satisfaction in the Bangladeshi banking sector. 


\subsection{Assurance}

Assurance has been perceived as employees' courtesy, knowledge, and their capability to allocation assurance as well as trust to customers (Parasuraman et al., 1994). The views on the standing of assurance among service quality dimensions are diverse. Assurance is placed as first service quality dimension by Gronroos(1988), although Parasuraman et al., (1994) placed it in fourth place. Assurance underlies observance customers knowledgeable in their natural language and eavesdropping to them, notwithstanding of their educational level, age, and nationality. Parasuraman et al., (1994) stated that assurance designates the attitudes of the employees and their behavior, and the staff's skill to deliver approachable, trustworthy, well-mannered, as well as competent services. Pakurár et al., (2019) found a positive link between banking customer satisfaction and assurance dimension. Therefore, the following hypothesis is propose:

H2: Assurance affects customer satisfaction in the Bangladeshi banking sector.

\subsection{Responsiveness}

Parasuraman et al., (1994) emphasized that the responsiveness of enthusiastic employees encompasses the practice of telling customers accurately when possessions will be completed, generous them unbroken attention, encouraging services, and answering in accord with their requests. Responsiveness was considered the third dimension in SERVQUAL prototypical. The readiness of employees to deliver the mandatory service at any time lacking any problem will have an influence on customer satisfaction (Lau et al., 2013). Thus, we propose the following hypothesis:

H3: Responsiveness effects customer satisfaction in the Bangladeshi banking sector.

\subsection{Tangibles}

Parasuraman et al. (1985), Parasuraman et al. (1988) and Parasuraman et al. (1994) classify tangibles as physical amenities (equipment, personnel, as well as communications resources). It is the physical copy of the service that customers will use to evaluate quality. Tangibles are related to the physical amenities, tools, and machines recycled in order to deliver the service, and illustrations of the services, such as statements, cards (debit and credit), speed, and efficiency of transactions. Numerous freedoms are comprised in tangibles such as external appearance, counters in the bank, overdraft facilities, opening hours, and speed and efficiency of transactions. Parasuraman et al. (1988) specified that tangibles have the same prominence as empathy. Sultana and Das (2016) considers tangibles as a similar component, showing relevance across various cultures. In the healthcare sector, tangibles aspect has a significant effect on patients' behavioral belief (Lee, 2017). In the banking sector, there is evidence that there is an important impact of tangibility on customer satisfaction (Sanjuq, 2014). Hence, the following hypothesis is proposed:

H4: Tangibles affects customer satisfaction in the Bangladeshi banking sector.

\subsection{Empathy}

Customers need to have the impression that they are important for the company delivering services. Empathy underlies consideration, paying personal attention, as well as delivering services to customers (Parasuraman et al., 1994). The essence of empathy is assigning the feeling that the customer is exclusive and distinct. Parasuraman et al. (1994) point out that quantitative research that have acknowledged service quality prototypical dimensions have charity safety, trustworthiness, as well as contact to extent empathy. Potluri et al. (2016) described empathy as the capability to take care of customers and encompass devotion to them independently, particularly while giving services. Thus, we proposed the following hypothesis:

H5: Empathy affects customer satisfaction in the Bangladeshi banking sector.

\subsection{Access to Service}

Yarimoglu (2014) describes access as accessibility and affluence of contact. The service is effortlessly reachable by telephone, the waiting time to receive the service is not long, and there are suitable hours of operation, as well as the service capacity is in a suitable location. Access underlies the ease as well as suitability with which customers can use the services that banks offers. Accessibility and ease of contact are the two most significant essentials of approachability. Research has shown that better approachability to services results in improved customer satisfaction (Flavian et al., 2004). As per most effective dimensions of service image, availability of services may have an important or unintended impact on a bank's customer satisfaction as well as loyalty (Ladhari et al., 2011). Hence, the following hypothesis is proposed:

H6: Access to service affects customer satisfaction in the Bangladeshi banking sector. 


\subsection{Employee Competence}

An ideal service is the result of numerous combined factors associated to separate service, employee competence as well as organizational strategies that uniform suitable skills. Human competency is one of the utmost collective areas complicated in the management of people at work (Omotayo et al., 2014). It is actually problematic to appreciate life without productive work, as well as positive or negative responses whereas these responses express just how satisfied or dissatisfied one is with one's work. Haddad (2017) expresses that competences comprise of knowledge, skills, abilities, values, motivation, initiative, and selfcontrol. Research argued that employee competence has a strong direct influence on customer satisfaction (Jianu et al., 2016). Hence, we propose the following hypothesis:

H7: Employee competences effect customer satisfaction in the Bangladeshi banking sector.

\section{Methodology}

In this study, the sample population is the banking customers in Bangladesh who used different private banks. For sampling purpose, random sampling technique was applied in this research, which was a non-probability approach. A survey questionnaire was distributed among those banking customers at different bank branch locations in Bangladesh. To collect the sample data, a team of eight MBA students was trained and they visited various bank branches for surveying the customers. On a periodic basis, the authors of this study also accompanied the survey team to monitor the data collection process. The total sample size of this study is 212 . The survey form has two parts; the first part collects demographic information of the customers and the second part is based on the variables with a Likert scale questionnaire. The study used a 5-point Likert scale, where ' 1 ' is 'strong disagree' and ' 5 ' is 'strong agree'. The survey questionnaire was developed based on previous literature, which is given below (Table 1):

Table 1: Referral Researches for Developing Survey Questionnaire

\begin{tabular}{|l|c|}
\hline Name of Study Variable & Referral Study \\
\hline Customer Satisfaction & Jahan, Ali and Asheq (2020) \\
\hline Reliability & \\
\hline Responsiveness & \multirow{2}{*}{ Pakurár et al (2019) } \\
\cline { 1 - 1 } Empathy & \\
\cline { 1 - 1 } Assurance & \\
\cline { 1 - 1 } Tangibles & \\
\hline Access to Service & \\
\hline Employee Competencies & \\
\hline
\end{tabular}

Table 2: Cronbach Alpha $(\alpha)$ value of all variables

\begin{tabular}{|l|c|}
\hline Variables & Cronbach Alpha ( $\boldsymbol{\alpha})$ value \\
\hline Customer Satisfaction & 0.860 \\
\hline Reliability & 0.734 \\
\hline Responsiveness & 0.728 \\
\hline Empathy & 0.794 \\
\hline Assurance & 0.774 \\
\hline Tangibles & 0.781 \\
\hline Access to Service & 0.729 \\
\hline Employee Competencies & 0.714 \\
\hline
\end{tabular}

For reliability purpose of all variables in the study, Cronbach's Alpha $(\alpha)$ value is considered and all the $(\alpha)$ values were found as reliable for all variables (Table 2). The study has also applied SPSS version 23.0 for statistical analysis and testing the hypotheses for better outcome. Then, the relevant statistical analysis was performed.

\section{Results and Discussion}

The study collected data from walking customers of various bank branches in Bangladesh. Table 3 represents the descriptive statistics of the respondents. It can be seen that the majority of the respondents were male customers (64\%) and 72 respondents were female (34\%). In terms of age, almost half of the respondents were aged between 31 and 40 (48\%), whereas 55 respondents were aged between 41 and $50(26 \%)$. As for the educational level, the majority of the respondents had at least honors or a bachelor's degree, 52 $(24.5 \%)$ respondents had only a diploma or other certificate degree, while 28 respondents had education up to higher secondary level (13.2\%). In terms of using banking service, it is found that 125 customers $(58.9 \%)$ had been using banking services from 1 to 5 years, 51 customers $(24 \%)$ had been using them for 0 to 1 years, and 28 customers (13.2\%) for 6 to 10 years.

To test the hypotheses, regression analysis was applied (Table 4). The regression model showed $35.4 \%$ variance in understanding the customer satisfaction of Bangladeshi bank customers by the dependent variables. Table 4 reveals that, except employee competency, reliability (H1), assurance (H2), responsiveness (H3), tangibles (H4), empathy (H5) and access to service (H6) were found to be significant predictors of banking customers' satisfaction in Bangladesh at 5\% significance level. In the research, seven dimensions of service quality measures positively affect the banking customers' level of satisfaction; this finding is consistent with past research. It does imply that higher degree of quality service will necessarily bring more satisfied customers to the 
banking or business firms. In this research, $\mathrm{H} 1$ is accepted, meaning that banking services need to be more reliable for the customers so that they will be satisfied and again come back to the bank.

$\mathrm{H} 2$ is also accepted, which reveals that banks need to provide well presented, trusted, and assured services to the clients to satisfy them. Responsiveness is conceived as a positive indicator of customer satisfaction as $\mathrm{H} 3$ is accepted. It implies that banking services have to be more responsive and bank employees are encouraged to pay more attention to customer's needs. Tangibles is found as significant predictor of banking customer satisfaction as $\mathrm{H} 4$ is accepted $(p>0.05)$.

Table 3: Descriptive Statistics

\begin{tabular}{|l|c|c|}
\hline Description & Frequency & Percent \\
\hline Gender & & \\
\hline Male & 140 & 64.1 \\
\hline Female & 72 & 33.9 \\
\hline Age & & \\
\hline 21 to 30 years & 42 & 19.8 \\
\hline 31 to 40 years & 102 & 48.1 \\
\hline 41 to 50 years & 55 & 25.9 \\
\hline More than 50 years & 13 & 6.2 \\
\hline Educational Level & & \\
\hline Up to Higher Secondary & 28 & 13.2 \\
\hline Bachelor/Honors degree & 92 & 43.4 \\
\hline Master/MBA & 40 & 18.9 \\
\hline Diploma/others & 52 & 24.5 \\
\hline Length of using banking service & & \\
\hline 0 to 1 years & 51 & 24.1 \\
\hline 1 to 5 years & 125 & 58.9 \\
\hline 6 to 10 years & 28 & 13.2 \\
\hline More than 10 years & 8 & 3.8 \\
\hline
\end{tabular}

The result is consistent with other research (Sultana \& Das, 2016). H5 is found as acceptable at 5\% significance degree, which means that empathy is a significant determinant of banking customer satisfaction. It implies that banking services provided to individuals need to be sincere and empathetic toward the bank clients. Access to service (H6) is also a significant variable of customer satisfaction in the Bangladeshi banking sector and the result is agrees with other studies (Pakurár et al., 2019). It does imply that banks need to provide uninterrupted banking services to the customers to satisfy them. Employee competence is found as an insignificant factor customer satisfaction in the banking industry. Perhaps, the bank clients and other customers are more focused on the banking transaction in real-time rather than the competency level of bank employees.

\section{Conclusions}

To retain an excellent service as well as to progress with a better-integrated system, it is important for the business organizations to appreciate the attitudes of the customer. Development of a tool to measure the satisfaction of customers is crucial for the banking service industry, especially in a developing country like Bangladesh. Essentially, service quality consists of seven dimensions: tangibles, responsiveness, empathy, assurance, reliability, access, and employee competence. The studies resulted in four sub-scales that can be pragmatic as suitable managerial measuring scales for customer satisfaction.

On the basis of this research, it is suggested that the following aspects be pragmatic for the dimension of customer satisfaction in the area inquired: professional features, caring, financial aspect, and tangibility. Also, for better and advanced service quality, bank management could adopt updated technological gateways such as mobile banking service (Akhter et al., 2020). The Bangladeshi banking system needs to provide secured banking facilities to the customers. However, banks need to be more radical concerning interrelating, accessing, and online consultancy

Table 4: Regression Analysis

\begin{tabular}{|l|c|c|c|c|c|c|}
\hline & Beta-value & $\boldsymbol{t}$ - value & Sig. & Tolerance & VIF & \\
\hline Reliability & 0.172 & 2.704 & 0.007 & 0.877 & 1.140 & Accepted \\
\hline Responsiveness & 0.138 & 2.060 & 0.041 & 0.788 & 1.268 & Accepted \\
\hline Empathy & 0.335 & 4.414 & 0.000 & 0.320 & 3.121 & Accepted \\
\hline Assurance & 0.210 & 3.239 & 0.001 & 0.839 & 1.191 & Accepted \\
\hline Tangibles & 0.162 & 2.249 & 0.026 & 0.837 & 1.195 & Accepted \\
\hline Access to Service & 0.176 & 2.496 & 0.013 & 0.678 & 1.474 & Accepted \\
\hline Employee Competencies & 0.165 & 0.870 & 0.386 & 0.708 & 1.412 & Rejected \\
\hline$R^{2}=0.354$, Durbin Watson value= 2.160 & & & \\
\hline
\end{tabular}


with customers to expand service quality in the future. Finally, banks need to invest in improvement to the quality of amenities, machinery and technologies to familiarize themselves with to the expansion of smartphone, laptop, Internet, and social network to maximize the productivity of the physical facilities, machinery, technologies of the bank in serving customers.

\section{References}

Akhter, A., Asheq, A. A., Hossain, M. U., \& Karim, M. K. (2020). Exploring customer intentions to adopt mobile banking services: evidence from a developing country. Banks and Bank Systems, 15(2), 105-116.

Angelova, B., \& Zekiri, J. (2011). Measuring customer satisfaction with service quality using American Customer Satisfaction Model (ACSI Model). International Journal of Academic Research in Business and Social Sciences, 1(3), 232.

Boonlertvanich, K. (2019). Service quality, satisfaction, trust, and loyalty: the moderating role of main-bank and wealth status. International Journal of Bank Marketing, 37(1), 278-302.

Baumann, C., Hoadley, S., Hamin, H., \& Nugraha, A. (2017). Competitiveness vis-à-vis service quality as drivers of customer loyalty mediated by perceptions of regulation and stability in steady and volatile markets. Journal of Retailing and Consumer Services, 36, 62-74.

Flavian, C., Torres, E., \& Guinalıu, M. (2004). Corporate Image Measurement A Further Problem for the Tangibilization of Internet Banking Services. International Journal of Bank Marketing, 22(5), 366-384.

Gronroos, C. (1988). Service quality: The six criteria of good perceived service. Review of Business, 9(3), 10-13.

Haddad, H. (2017). Impact of Human Competencies on Caritas Jordan Employees Performance. Journal of Resources Development and Management, 1(28), 57-71.

Hossain, M. U., \& Asheq, A. A. (2020). Do Leadership Orientation and Proactive Personality Influence Social Entrepreneurial Intention? International Journal of Management and Enterprise Development, 19(2), 109-125.

Hossain, M. U., Asheq, A. A., \& Arifuzzaman, S. M. (2019). Entrepreneurial intention of Bangladeshi students: impact of individual and contextual factors. Problems and Perspectives in Management, 17(4), 493-503.

Jahan, N., Ali, M. J., \& Asheq, A. A. (2020). Examining the Key Determinants of Customer Satisfaction Internet Banking Services in Bangladesh, Academy of Strategic Management Journal, 19(1), 1-6.

Jianu, I., Țurlea, C., \& Guşatu, I. (2016). The Reporting and Sustainable Business Marketing. Sustainability, 8(1), 23. https://doi.org/10.3390/su8010023

Ladhari, R., Souiden, N., \& Ladhari, I. (2011). Determinants of loyalty and recommendation: The role of perceived service quality, emotional satisfaction and image. Journal of Financial Services Marketing, 16(2), 111-124.

Lam, T. K. (2002). Making sense of SERVQUAL's dimensions to the Chinese customers in Macau. Journal of Market-Focused Management, 5(1), 43-58.

Lau, M. M., Cheung, R., Lam, A. Y., \& Chu, Y. T. (2013). Measuring service quality in the banking industry: a Hong Kong based study. Contemporary Management Research, 9(3), 263-282.

Le, Q. H., Nguyen, L. T. T., \& Pham, N. T. A. (2019). The Impact of Click and Collect's Service Quality on Customer Emotion and Purchase Decision: A Case Study of Mobile World in Vietnam. Journal of Asian Finance, Economics and Business, 6(1), 195-203. http://doi.org/10.13106/jafeb.2019.vol6.no1.195

Lee, J. W. (2017). Critical factors affecting consumer acceptance of online health communication: an application of service quality models. Journal of Asian Finance, Economics and Business, 4(3), 85-94. http://dx.doi.org/10.13106/jafeb.2017.vol4.no3.85

Nguyen, D. T., Pham, V. T., Tran, D. M., \& Pham, D.B.T. (2020). Impact of Service Quality, Customer Satisfaction and Switching Costs on Customer Loyalty. Journal of Asian Finance, Economics and Business, 7(8), 395-405. https://doi. org/10.13106/jafeb.2020.vol7.no8.395

Omotayo, A. O., Salau, O. P., \& Falola, H. O. (2014). Modeling the relationship between motivating factors; Employee'retention; and job satisfaction in the Nigerian banking industry. Journal of Management Policies and Practices, 2(2), 63-83.

Pakurár, M., Haddad, H., Nagy, J., Popp, J., \& Oláh, J. (2019). The service quality dimensions that affect customer satisfaction in the Jordanian banking sector. Sustainability, 11(4), 1113. https://doi.org/10.3390/su11041113

Parasuraman, A., Zeithaml, V. A., \& Berry, L. L. (1985). A conceptual model of service quality and its implications for future research. Journal of Marketing, 49(4), 41-50.

Parasuraman, A., Zeithaml, V. A., \& Berry, L. L. (1988). Servqual: A multiple-item scale for measuring consumer perceptions of service quality. Journal of Retailing, 64(1), 12-40.

Parasuraman, A., Berry, L. L., \& Zeithaml, V. A. (1991). Understanding customer expectations of service. Sloan Management Review, 32(3), 39-48.

Parasuraman, A., Zeithaml, V. A., \& Berry, L. L. (1994). Reassessment of expectations as a comparison standard in measuring service quality: implications for further research. Journal of Marketing, 58(1), 111-124.

Potluri, R. M., Angati, S. R., \& Narayana, M. S. (2016). A structural compendium on service quality and customer satisfaction: A survey of banks in India. Journal of Transnational Management, 21(1), 12-28.

Rauch, D. A., Collins, M. D., Nale, R. D., \& Barr, P. B. (2015). Measuring service quality in mid-scale hotels. International Journal of Contemporary Hospitality Management, 27, 87-106.

Sanjuq, G. (2014). The impact of service quality delivery on customer satisfaction in the banking sector in Riyadh, Saudi 
Arabia. International Journal of Business Administration, 5(4), 77.

Sultana, S., \& Das, T. I. S. (2016). Measuring Customer Satisfaction through SERVQUAL Model: A Study on Beauty Parlors in Chittagong. European Journal of Business and Management, 8, 97-108.

Tabash, M. I., Albugami, M. A., Salim, M., \& Akhtar, A. (2019). Service quality dimensions of E-retailing of Islamic banks and its impact on customer satisfaction: An empirical investigation of kingdom of Saudi Arabia. Journal of Asian Finance, Economics and Business, 6(3), 225-234. https://doi. org/10.13106/jafeb.2019.vol6.no3.225
Tran, V. D. (2020). Assessing the effects of service quality, experience value, relationship quality on behavioral intentions. Journal of Asian Finance, Economics, and Business, 7(3), 167-175. https://doi.org/10.13106/jafeb.2020.vol7.no3.167

Titko, J., Lace, N., \& Kozlovskis, K. (2013). Service quality in banking: developing and testing measurement instrument with Latvian sample data. Acta Universitatis Agriculturae et Silviculturae Mendelianae Brunensis, 61(2), 507-515.

Yarimoglu, E. K. (2014). A review on dimensions of service quality models. Journal of Marketing Management, 2(2), 79-93. 